\title{
Pengaruh Dana Desa dalam Mengentaskan Kemiskinan Penduduk Desa
}

\author{
Eri Bukhari ${ }^{1, *}$ \\ ${ }^{1}$ Fakultas Ekonomi dan Bisnis; Universitas Bhayangkara Jakarta Raya; Jl. Raya Perjuangan, \\ Marga Mulya Bekasi 17121, telp/fax 021-88955882/ 021-8895883, e-mail: \\ eribukhari@yahoo.com \\ * Korespondensi: e-mail: eri bukhari@yahoo.com
}

Submitted: 19/03/2021; Revised: 29/03/2021; Accepted: 11/05/2021; Published: 27/05/2021

\begin{abstract}
Poverty is synonymous with deficiency and underdevelopment. The current phenomenon is the increasingly rapid flow of urbanization from villages to cities which results in the number of rural residents decreasing, even now, the number is less when compared to the population in urban areas. The result of urbanization has left a group of poor people living in the village, thus statistically increasing the number of poor people in rural areas beyond the number of poor people in urban areas. One of the government's efforts to overcome this problem is the provision of Village Funds, which have been budgeted through the State Budget since 2015. The purpose of this study is to determine whether the Village Fund program is sufficiently influential in efforts to alleviate poverty, especially for villagers. The variables used are the amount of village funds and the number of rural poor. The research method used is explanatory research, namely quantitative research using secondary data in the form of village fund reports and data on the rural poor in 2015-2019. In addition, this study uses the SPSS 25 statistical tool. The results of this study indicate that the number of rural poor people can be affected by village funds budgeted in the State Revenue and Expenditure Budget, namely the provision of village funds has a significant negative effect. In other words, the program can reduce the number of rural poor people.
\end{abstract}

Keywords: Urbanization, Poverty, Village Fund

\begin{abstract}
Abstrak
Kemiskinan identik dengan kekurangan dan keterbelakangan. Fenomena yang ada sekarang ini adalah semakin derasnya arus urbanisasi dari desa ke kota yang mengakibatkan jumlah penduduk desa berkurang, bahkan saat ini jumlahnya lebih sedikit jika dibandingkan dengan jumlah penduduk di wilayah perkotaan. Akibat dari urbanisasi ini meninggalkan sekelompok penduduk miskin yang tetap bermukim di desa, sehingga secara statistik menaikkan jumlah penduduk miskin di wilayah pedesaan melebihi jumlah penduduk miskin di wilayah perkotaan. Salah satu usaha pemerintah mengatasi masalah ini adalah pemberian Dana Desa, yang mulai dianggarkan melalui APBN sejak tahun 2015. Tujuan penelitian ini adalah untuk mengetahui apakah program Dana Desa cukup berpengaruh dalam usaha mengentaskan kemiskinan khususnya bagi penduduk desa. Variabel yang gunakan adalah jumlah dana desa dan jumlah penduduk miskin pedesaan. Metode penetitian yang digunakan adalah explanatory research yaitu penelitian kuantitatif dengan menggunakan data sekunder berupa laporan dana desa dan data penduduk miskin pedesaan tahun 2015-2019. Selain itu penelitian ini menggunakan alat statistik SPSS 25. Hasil penelitian ini menunjukkan bahwa jumlah penduduk miskin pedesaan dapat dipengaruhi oleh dana desa yang dianggarkan dalam Anggaran Pendapatan dan Belanja Negara, yaitu pemberian dana desa berpengaruh negatif signifikan. Dengan kata lain program tersebut dapat mengurangi jumlah penduduk miskin pedesaan.
\end{abstract}

Kata kunci: Urbanisasi, Kemiskinan, Dana Desa 


\section{Pendahuluan}

Kemiskinan dan ketidakmerataan pendapatan adalah salah satu masalah pokok dalam pembangunan suatu negara terutama bagi negara-negara yang sedang berkembang. Fenomena ini menjadi persoalan bagi banyak negara termasuk Indonesia, meskipun sudah menjadi anggota G20, tempatt kumpulan bagi negara yang mempunyai peran dan pengaruh penting terhadap masalah ekonomi global, dimana persoalan tersebut masih menjadi sesuatu yang krusial. Berdasarkan survey dari worldmeter tahun 2019 jumlah penduduk Indonesia sekitar 270, 6 juta jiwa dan dari jumlah tersebut 151 juta jiwa atau kisaran 55,8\% tinggal di perkotaan, sisanya 119, 6 juta jiwa atau kisaran 44,2\% tinggal di pedesaan. Pada tahun 2020 diproyeksikan jumlah penduduk Indonesia sekitar 273, 5 juta jiwa, dari angka tersebut jumlah proporsi penduduk yang bermukim di perkotaan sekitar 56,4\% dan sisanya $43,7 \%$ tinggal di pedesaan. Berdasarkan data tersebut ternyata jumlah penduduk Indonesia mayoritas hidup di daerah perkotaan, hal ini akibat dari arus urbanisasi dari desa ke kota.

Tabel 1. Perbandingan Jumlah Penduduk Desa dan Kota Tahun 2019 - 2020

\begin{tabular}{ccc}
\hline Tahun & Perkotaan & Pedesaan \\
\hline 1. & 151 Juta Jiwa & 119,6 Juta Jiwa \\
\hline 2. & 154,2 Juta Jiwa & 129,3 juta jiwa \\
\hline
\end{tabular}

Sumber: Hasil Penelitian (2020)

Fenomena banyaknya jumlah penduduk yang bermukim dan tinggal di kota dari pada di desa menjadi menjadi pertanyaan penelitian bagi penulis, yaitu apa yang terjadi di desa sehingga banyak terjadi arus urbanisasi dari desa ke kota. Hipotesis sementara adalah persoalan kemiskinan dan ketidakmerataan pendapatan, sehingga banyak penduduk yang beralih untuk hijrah dan tinggal di kota demi bertahan hidup ataupun memperoleh kehidupan yang lebih baik bagi individu maupun keluarganya. Untuk lebih jelasnya bisa kita lihat perbandingan jumlah penduduk miskin antara desa dan kota seperti dalam tabel dibawah ini Tabel 2. Persentase Jumlah Penduduk Misikin Wilayah Perkotaan dan Pedesaan Tahun 2019 2020

\begin{tabular}{ccc}
\hline Tahun & Perkotaan & Pedesaan \\
\hline 1. & $6,69 \%$ & $12,85 \%$ \\
\hline 2. & $7,38 \%$ & $12,82 \%$ \\
\hline
\end{tabular}

Sumber: Hasil Penelitian (2020)

Berdasarkan kedua tabel terlihat perbandingan jumlah penduduk miskin di pedesaan ternyata lebih besar jika dibandingkan dengan jumlah penduduk miskin di perkotaan, tetapi meskipun jumlah penduduk yang tinggal diwilayah perkotaan lebih banyak dibandingkan yang tinggal di pedesaan, ternyata jumlah penduduk miskin masih didominasi oleh penduduk yang bermukim dan tinggal diwilayah pedesaan, yang secara persentase jumlahnya hampir 2 kali lipat dibandingkan penduduk perkotaan, hal ini menunjukkan jumlah penduduk miskin didesa lebih besar jika dibandingkan penduduk yang tinggal di kota.

Konsep dari kemiskinan itu adalah kemampuan seseorang dalam memenuhi kebutuhan dasar (basic needs approach). Melalui pendekatan ini, sudut pandang kemiskinan itu sebagai 
sesuatu ketidakmampuan dari sisi ekonomi dalam memenuhi kebutuhan dasar makanan termasuk dan bukan makanan yang diukur dari sisi pengeluaran., sehingga definisi dari penduduk miskin tersebut adalah adalah penduduk yang dalam kehidupannya memiliki pengeluaran rata-rata perkapita perbulan dibawah garis kemiskinan (Badan Pusat Statistik, 2017). Berdasarkan SUSENAS tahun 2002 menunjukkan bahwa hampir $70 \%$ dari jumlah penduduk miskin di pedesaan memiliki pekerjaan di sektor pertanian, bahkan kegiatan pertanian mempunyai peran yang dominan sebagai sumber pendapatan bagi orang miskin di daerah perkotaan. Bukti ini merefleksikan suatu hal yang jelas, yakni orang disektor pertanian umumnya selalu lebih miskin dibandingkan orang yang sumber pendapatan utamanya dari sector lain, terutama dari sektor manufaktur, perdagangan, jasa, dan konstruksi. (Tambunan.TTH, 2012). Kondisi ini yang menjadi faktor utama yang mendorong penduduk desa untuk melakukan urbanisasi ke kota demi memperbaiki kehidupan ekonominya, sehingga mengakibatkan kondisi saat ini menjadi berbalik dimana jumlah penduduk kota lebih banyak dibanding di desa Alasan klasik adalah karena pada umumnya terbatasnya sarana pendidikan di desa, sehingga dibanyak kepala rumah tangga miskin berpendidikan setingkat sekolah dasar dan memiliki keterbatasan dalam mengakses bantuan kredit untuk usaha (Nasution, 2016).

Pemerintah Indonesia dalam hal ini Badan Pusat Statistik mempunyai indikator tersendiri dalam menentukan bagaimana seseorang termasuk dalam kategori sebagai penduduk miskin, yaitu (i) Garis Kemiskinan (GK) didapat dari hasil penjumlahan dari Garis Kemiskinan Makanan (GKM) dan Garis Kemiskinan Non Makanan (GKNM). Penduduk di suatu negara yang memiliki pengeluaran rata-rata perkapita per bulan dibawah Garis Kemiskinan maka dikategorikan sebagai penduduk miskin; (ii) Garis Kemiskinan Makanan (GKM) yang didapat nilai pengeluaran kebutuhan minimum makanan yang kemudian disetarakan dengan 2100 kilokalori perkapita perhari. Paket kebutuhan dasar makanan berupa komoditi yang diwakili oleh 52 jenis komoditi (padi-padian, umbi-umbian, ikan, daging, telur dan susu, sayuran, kacang-kacangan, buah-buahan, minyak dan lemak, dII) ;(iii) Garis Kemiskinan Non Makanan (GKNM) adalah kebutuhan lain selain makanan yang minimum harus terpenuhi yaitu perumahan, sandang, pendidikan dan juga kesehatan. Paket komoditi kebutuhan dasar non makanan ini diwakili 51 jenis komoditi wilayah perkotaan dan 47 jenis komoditi wilayah pedesaan (Badan Pusat Statistik, 2017).

Melepaskan diri dari belenggu kemiskinan merupakan sasaran pokok yang harus dicapai dalam setiap pembangunan, meskipun harus melewati perjuangan yang cukup lama termasuk negara Indonesia yang sudah 75 tahun merdeka. Berbicara tentang kemiskinan, tidak boleh terlepas juga dari pada pertumbuhan ekonomi, karena secara umum pembangunan disuatu negara sering dikaitkan dengan pertumbuhan output nasional dan pendapatan, ehingga terjadi hubungan segitiga (triangle) yaitu pertumbuhan, kemiskinan dan juga ketimpangan merupakan suatu hubungan timbal balik dan akan yang saling mempengaruhi satu sama lain.(Sudarlan, 2015). Untuk mencapai keseimbangan antara pertumbuhan ekonomi yang 
tinggi yang dapat mengurangi angka kemiskinan dan distribusi pendapatan yang merata maka diperlukan kebijakan pemerintah yang berkeadilan sosial, karena walaupun pertumbuhan ekonomi tinggi, tetapi jika tidak ada kebijakan pemerintah yang "pro orang miskin" pembagian keuntungan dari pertumbuhan tersebut tidak merata. Alasannya sederhana karena mekanisme pasar bekerja tidak sempurna; jadi perlu adanya intervensi pemerintah agar kelompok miskin juga bisa menikmati keuntungan tersebut.(Tambunan.TTH, 2012)

Desa dikatakan sebagai desa atau desa adat ataupun yang disebut dengan nama lain yang selanjutnya disebut Desa, adalah kesatuan masyarakat, dimana didalamnya terdapat hukum yang berlaku dan memiliki batas wilayah, dimana masyarakat didalamnya memilik hak dan wewenang dalam mengatur serta mengurus urusan pemerintahannya sendiri, untuk kepentingan masyarakat setempat dengan berpedoman kepada prakarsa masyarakat, hak asal usul, dan/atau hak tradisional yang diakui dan dihormati dalam sistem pemerintahan yang ada pada Negara Kesatuan Republik Indonesia(DPR, 2014) UndangUndang No.6 Tahun 2014 tentang Desa telah merubah paradigma tentang pengaturan desa, sehingga sebuah desa tidak lagi dianggap sebagai objek pembangunan, tetapi beralih peran sebagai subjek dan ujung tombak pembangunan dan juga peningkatan kesejahteraan masyarakat (Kemenkeu, 2017).

Pemerintah memiliki peran dalam pengelolaan keuangan publik, mulai dari tata kelola keuangan tertinggi yaitu pusat, daerah, sampai lingkup yang terkecil yaitu desa. Sebagai lingkup terkecil maka desa mempunyai peran yang sangat strategis sebagai penyalur antara pemerintah dengan masyarakat dan berhubungan langsung dengan kepentingan dan kebutuhan masyarakat setempat karena pada dasarnya kemajuan suatu negara dapat diidentifikasikan oleh kemajuan desa (Wicaksono et al., 2019).

Dalam usaha mengentaskan kemiskinan Pemerintah Republik Indonesia sejak tahun 2015 telah mengambil kebijakan berupa pemberian Dana Desa yang dialokasikan dalam APBN. Program ini merupakan bentuk dari implementasi dari poin ke tiga program Nawa Cita, yaitu membangun Indonesia dari pinggiran dengan memperkuat daerah-daerah dan desa. (Bukhari, 2018). Anggaran Dana Desa merupakan bagian dari Dana Transfer yang ada didalam APBN. Jumlah yang telah dianggarkan besarnya 10\% dari dan diluar Dana Transfer. Selama 5 tahun sejak awal pemberian Dana Desa, jumlahnya setiap tahun hampir selalu meningkat,sehingga dapat dikatakan kebijakan ini berjalan beriringan dengan sasaran pembangunan untuk wilayah perdesaan yang tercantum dalam RPJMN 2015-2019, sehingga diharapkan penggunaan dana desa perlu diarahkan untuk fokus kepada mendukung pengentasan desa tertinggal demi mendukung terwujudnya kemandirian desa (Buku Pintar Dana Desa, 2017).

Tujuan dari pemberian Dana Desa yaitu meningkatkan pelayanan publik di desa dengan (i) Mengentaskan kemiskinan; (ii) Memajukan perekonomian desa; (iii) Mengatasi kesenjangan pembangunan antardesa (iv) Memperkuat masyarakat desa sebagai subjek pembangunan (Kemenkeu, 2017), diharapkan dari tujuan tersebut tercapailah Sasaran 
Pengembangan Wilayah Perdesaan dalam RPJMN 2015-2019 yaitu: (i) Mengurangi jumlah desa tertinggal dari angka 26\% (2011) diangka 20\% (2019) (ii) Mengurangi desa tertinggal sampai dengan 5.000 desa atau meningkatkan desa mandiri semininal mungkin menjadi 2.000 desa (Buku Pintar Dana Desa, 2017).

Untuk mengetahui dampak program Pemerintah mengenai pengalokasian Dana Desa terhadap peningkatan ekonomi yang meliputi pendapatan masyarakat desa diperlukan sebuah studi ilmiah untuk mengetahui efektivitas pemanfaatan dana desa dalam mengentaskan kemiskinan (Wahyuddin et al., 2019), sehingga berdasarkan fenomena dyang disebutkan dalam latar belakang tersebut diatas penulis bermaksud membuat tulisan tentang Pengaruh Dana Desa terhadap Mengentasan Kemiskinan Penduduk Desa, dimana tujuan penulisan ini adalah untuk mengetahui Apakah ada pengaruhnya pemberian Dana Desa tersebut dalam usaha pemerintah untuk mengentaskan Kemiskinan Penduduk Pedesaan selama 5 tahun pemberian Dana Desa tersebut.

\section{Metodologi Penelitian}

Penelitian ini menggunakan pendekatan kuantitatif dengan explanatory research sehingga akan menjelaskan apakah variabel bebas Dana Desa akan mempengaruhi jumlah penduduk miskin pedesaan sebagai variabel terikat. Data penelitian diperoleh dari website Kementerian Keuangan dan Badan Pusat Statistik Republik Indonesia, berupa data Dana Desa yang telah diberikan selama lima tahun sejak awal diberlakukannya Kebijakan Dana Desa dalam APBN dan data tentang jumlah penduduk miskin yang ada di desa antara tahun 2015 sampai dengan tahun 2019, dimana data lima tahun terakhir tersebut dijadikan sampel penelitian.

Teknik analisis mengunakan analisis regresi linear sederhana karena hanya menggunakan 2 variabel, Dana Desa dan jumlah penduduk miskin pedesaan, masig-masing sebagai variabel bebas dan variable terikat. Tujuan dari analisis regersi digunakan untuk mengetahui pola secara matematis antara variabel independent $(X)$ dan variabel dependent $(Y)$, yaitu Dana Desa $(X)$ dan Jumlah Penduduk Misikin Pedesaan $(Y)$. sehingga didapat persamaaan regresi linear sederhana dirumuskan sebagai berikut:

$$
Y=a+b X
$$

Keterangan: $\mathrm{Y}$ : Variabel Terikat (Jumlah Penduduk Miskin Pedesaan); a: Bilangan Konstanta; X: Variabel Bebas (Dana Desa); b : Koefisien Regresi.

Pengujian Hipotesis yang dilakukan mengunakan Uj-t melihat mengetahui pengaruh variabel independen Dana Desa $(X)$ terhadap Jumlah Penduduk Miskin Pedesaan ( $Y$ ). Hipotesis pertama adalah tidak ada pengaruh Dana Desa terhadap Pengentasan Jumlah Penduduk Miskin Desa, Hipotsesis kedua Terdapat pengaruh Dana Desa terhadap Pengentasakan Jumlah Penduduk Miskin Desa. Selain itu digunakan juga analisis koefisien determinasi yang berfungsi untuk mengukur seberapa besar model tersebut mampu 
menerangkan variabel dependen, dimana nilai koefisien determinasi tersebut adalah antara nol sampai dengan satu $\left(0<R^{2}<1\right)$, jika dalam penelitian ini nilai $R^{2}$ mendekati nol maka variabel independen bisa dikatakan tidak dapat menerangkan variabel dependen dan sebaliknya jika besar nilai $R^{2}$ mendekati 1 (satu) maka semakin baik karena persentase pengaruh yang diberikan variabel independen terhadap variabel dependen adalah mendekati sempurna karena mampu menjelaskan $100 \%$ variabel dependen.

Penelitian serupa pernah dilakukan oleh Wahyuddin secara parsial di suatu kecamatan provinsi Aceh yang berjudul Efektivitas Pemanfaatan Dana Desa dalam Mengentaskan Kemiskinan di Kecamatan Kuala Kabupaten Nagan Raya, dimana hasilnya adalah Variabel Dana Desa berpengaruh negatif dan signifikan terhadap kemiskinan desa sebesar 0,01 ini memberikan indikasi jika setiap penambahan 1\% Alokasi Dana Desa, maka akan menurunkan kemiskinan desa sebesar 0,01\% (Wahyuddin et al., 2019).

\section{Hasil dan Pembahasan}

Pemberian Dana Desa yang mulai diberikan sejak tahun 2015 ini sejalan dengan RPJMN tahun 2015 - 2019 dan besarannya meningkat dari tahun-ketahun. Pada awalnya jumlahnya memang masih sangat sedikit hanya Rp. 9,06 Milyar -, sangat jauh dari jumlah minimal $10 \%$ dari dana transfer dan hasilnya belum memberikan kontribusi yang pantas menimbang luasnya wilayah Indonesia apalagi yang sebagian besar wilayahnya adalah lautan dan terdapat beribu-beribu jumlah desa terpencil yang tersebar. Tahun berikutnya 2017 Dana Desa mengalami peningkatan yang cukup signifikan menjadi Rp. 46.98 Milyar,-, terjadi kenaikan $5 \mathrm{x}$ lipat lebih dari tahun sebelumnya, dan secara nominal terdapat penurunan jumlah penduduk miskin. Tahun berikutnya Dana Desa terus mengalami kenaikan, dimana tahun 2017 dan 2018 berada pada jumlah yang sama yaitu Rp. 60 Milyar, namun angka tersebut belum mencapai 10\% dari Dana Transfer, baru pada tahun 2019 angkanya hampir mendekati $10 \%$ dari dan diluar dana transfer. Yaitu sebesar Rp. 70 Milyar dan jumlah penduduk miskin secara nominal juga ikut turun. Datanya bisa dilihat dalam tabel berikut:

Tabel 3. Perkembangan Pemberian Dana Desa Tahun 2015 - 2019

\begin{tabular}{lcc}
\hline Tahun & $\begin{array}{c}\text { Dana Desa } \\
\text { (Rupiah) }\end{array}$ & $\begin{array}{c}\text { Jumlah Penduduk Miskin Desa } \\
\text { (Juta Jiwa) }\end{array}$ \\
\hline 2015 & 9.060 .000 .000 & 28.513 .570 \\
\hline 2016 & 46.980 .000 .000 & 27.764 .320 \\
\hline 2017 & 60.000 .000 .000 & 26.582 .990 \\
\hline 2018 & 60.000 .000 .000 & 25.674 .580 \\
\hline 2019 & 70.000 .000 .000 & 24.785 .870 \\
\hline
\end{tabular}

Sumber: Hasil Penelitian (2020)

Berdasarkan Tabel 4 hasil pengolahan data SPSS 25 dengan variabel Bebas Dana Desa dan Variabel Terikat Jumlah Penduduk Miskin Pedesaan dapat dilihat sebagai berikut: 
Tabel 4. Hasil Pengolahan Data Dua Variabel

\begin{tabular}{|c|c|c|c|c|c|c|c|}
\hline \multirow[b]{5}{*}{ Model } & \multicolumn{3}{|c|}{ Coefficients $^{a}$} & & & & \\
\hline & \multirow{2}{*}{\multicolumn{2}{|c|}{ Unstandardized }} & \multicolumn{3}{|l|}{ Standardize } & \multirow[b]{2}{*}{ Collinearity } & \\
\hline & & & $d$ & & & & \\
\hline & \multicolumn{2}{|c|}{ Coefficients } & Coefficients & \multirow[b]{2}{*}{$\mathrm{T}$} & \multirow[b]{2}{*}{ Sig. } & \multicolumn{2}{|l|}{ Statistics } \\
\hline & B & Std. Error & Beta & & & Tolerance & IF \\
\hline \multirow[t]{2}{*}{ (Constant) } & 29407302.596 & 863701.23 & & 34.048 & .000 & & \\
\hline & & 6 & & & & & \\
\hline \multirow[t]{2}{*}{ Jumlah_Dana_Desa } & $-5.507 E-8$ & .000 & - & & .040 & 1.000 & \\
\hline & & & .895 & 3.471 & & & .000 \\
\hline
\end{tabular}

a. Dependent Variable: Jumlah_Penduduk_Miskin

Sumber: Hasil Pengolahan Data (2020)

\subsection{Uji-T}

Hipotesis statistik yang diajukan yaitu $\mathrm{Ha}=$ Variabel Dana Desa berpengaruh signifikan terhadap Jumlah Penduduk Miskin Pedesaan. Pada tabel 4 diperoleh nilai signifikansi sebesar $0,04<0,05$ dengan diperoleh t-hitung sebesar 3,471 sedangkan t-tabel sebesar 2,571 berarti $3,471>2.571$ yang artinya Ha diterima. Hasil analisis tersebut menyimpulkan Pemberian Dana Desa $(\mathrm{X})$ terhadap Jumlah Penduduk Miskin Pedesaan $(\mathrm{Y})$ dengan demikian perubahan naik atau turunnya jumlah Dana Desa akan mempengaruhi besarnya Jumlah Penduduk Miskin Pedesaan.

\subsection{Analisis Regresi Sederhana}

Hasil pengujian pada Tabel 4 juga menunjukkan model regresi sederhana, dimana dapat diperoleh persamaan model regresi linear sebagai berikut:

$\mathrm{Y}=29.407 .303-0,00000005507 \mathrm{X}$

Berdasarkan persamaan regresi dapat dilihat bahwa: Nilai Konstanta sebesar 29.407.303 menunjukkan pengaruh negatif pada variabel bebas yaitu Dana Desa. Jika Dana Desa sama dengan nol, maka variabel terikat Jumlah Penduduk Miskin Desa ( $Y$ ) akan sebesar 29.407.303 juta jiwa, dan kenaikan Dana Desa satu satuan akan menurunkan rataan sebaran jumlah penduduk miskin pedesaan sebesar 0,00000005507 satuan. Atau dengan kata lain, jika Dana Desa digelontorkan sebesar Rp. 10.000.000,- maka penduduk miskin pedesaan akan berkurang 5,507 orang atau sama dengan 6 orang.

\subsection{Uji Koefisien Determinasi}

Analisis koefisien determinasi merupakan analisis yang digunakan untuk mengukur seberapa besar kontribusi variabel bebas terhadap variabel terikat. Apabila nilai $R^{2}$ mendekati nol maka variabel independen secara keseluruhan tidak dapat menjelaskan variasi variabel dependen. Sebaliknya jika besar nilai $R^{2}$ mendekati 1 (satu) maka semakin baik karena persentase pengaruh yang diberikan variabel independen terhadap variabel dependen adalah sempurna. Hasil analisis data melalui program SPSS dapat dilihat dari tabel berikut: 
Tabel 5. Koefisien Determinasi

\begin{tabular}{|c|c|c|c|c|c|c|}
\hline & \multicolumn{6}{|c|}{ Model Summary } \\
\hline & & & & Adjusted & R Std. Error of the & \\
\hline Model & & $\mathrm{R}$ & R Square & Square & Estimate & Durbin-Watson \\
\hline 1 & $.895^{\mathrm{a}}$ & & .801 & .734 & 779509.050 & 1.571 \\
\hline
\end{tabular}

a. Predictors: (Constant), Jumlah_Dana_Desa

b. Dependent Variable: Jumlah_Penduduk_Miskin

Sumber: Hasil Pengolahan Data (2020)

Berdasarkan tabel 5 dapat dilihat koefisien determinasi $\left(R^{2}\right)$ sebesar 0,801 artinya menunjukkan bahwa presentase sumbangan pengaruh variabel independen Dana Desa terhadap variabel terikat jumlah penduduk miskin di desa sebesar $80,1 \%$. sedangkan $19,9 \%$ dipengaruhi oleh faktor lain yang tidak dibahas pada penelitian ini.

Sedangkan jika diukur dengan menggunakan derajat keratan 2 variabel antara Dana Desa dan jumlah penduduk miskin di desa adalah 0,895, sehingga dapat dikatakan hubungan anatara Dana Desa dan jumlah penduduk miskin desa cukut kuat.

\subsection{Pembahasan}

Dana Desa yang merupakan program pemerintah dalam usaha mengentaskan kemiskinan bagi penduduk desa yang sudah tertuang dalam APBN secara nasional ternyata cukup berpengaruh signifikan, dimana setiap kenaikan Dana Desa sebesar Rp. 10.000.000,akan menurunkan jumlah penduduk miskin di desa sebesar 5, 507 orang atau sama dengan 6 orang. Bila dikalkulasi angka tersebut cukup baik, namun belum bisa mencerminkan semua desa yang ada. Hal ini sejalan dengan penelitian sebelumnya yang dilakukan oleh Wahyuddin, walaupun perbedaanya koefisiennya sangat jauh antara skala nasional dan skala kabupaten Secara parsial khususnya penelitian Dana Desa untuk Kabupaten Nagan Raya Propinsi Aceh yaitu setiap penambahan 1\% Dana Desa, maka akan menurunkan kemiskinan desa sebesar $0,01 \%$, perbedaannya penelitian tersebut tidak menjelaskan secara detail berapa jumlah Dana Desa yang dikeluarkan akan menurunkan jumlah penduduk miskin sekian jiwa.

Penelitian ini juga belum bisa menjawab apakah program Dana Desa tersebut memang benar-benar efektif mengentaskan penduduk miskin desa secara merata diseluruh Indonesia, mengingat jumlah desa yang sangat banyak dan tersebar di ribuan pulau yang ada, Faktor goegrafis adalah salah satu hambatan dalam penyaluran Dana Desa tersebut, khususnya beberapa propinsi yang berbentuk kepulauan seperti Kepri, Bangka Belitung dan. Disamping itu ada juga propinsi yang tingkat kepadatan penduduknya sangat jarang seperti di wilayah bagian timur Indonesia seperti Maluku, Maluku Utara, Papua dan Papua Barat, dimana tingkat kepadatan penduduknya hanya $21 \mathrm{jiwa} / \mathrm{km}^{2}$, sangat kontras perbandingannya dengan tingkat kepadatan penduduk di bagian barat Indonesia seperti di Jawa, Bali dan Nusa Tenggara yang mencapai $2.305 \mathrm{jiwa} / \mathrm{km}^{2}$ 


\section{Kesimpulan}

Pemberian Dana Desa selama 5 tahun terakhir sejak tahun 2015 - 2019 yang betujuan untuk mengentaskan kemiskinan khususnya bagi penduduk desa cukup memang cukup berpengaruh signifikan, namun efeknya dalam mengentaskan kemiskinan secara nasional belum terbukti berhasil, karena penelitain ini masih secara global belum terbukti merata bagi semua desa yang ada, tetapi walau bagaimanapun juga program ini sejalan program pemerintah melalui Nawa Cita, dan berjalan beriringan dengan RPJMN 2015 - 2019, dimana fase tersebut termasuk dalam tahap ketiga dari pelaksanaan Program 20 tahun RPJP Nasional tahun 2005 - 2025. Untuk melihat efek yang lebih realistis, diperlukan penelitian lebih lanjut secara parsial di propinsi yang wilayah geografisnya berupa kepulauan dimana luas lautannya lebih besar dibandingkan daratannya. $\mathrm{Hal}$-hal yang perlu diperhatikan kedepannya adalah: i) menciptakan formula baru yang lebih memfokuskan skala prioritas kepada propinsi yang angka kemiskinan penduduk pedesaannya sangat tinggi, sehingga diharapkan dapat mengejar ketertinggalan dalam pembangunan ; ii) meningkatkan kualitas pengelolaan Dana Desa agar penyaluran dana tersebut tepat sasaran dan diringi dengan pengawasan yang ketat untuk menghindari kebocoran; iii) dibentuk koordinator dalam pembagian Dana Desa berdasarkan wilayah barat, tengah dan timur Indonesia agar lebih mudah melakukan kontrol dan evaluasi pendistribusian dan penggunaan Dana Desa tersebut. Selain itu secara teknis untuk melihat efek yang lebih besar diharapkan kedepan penggunaan dana desa tersebut akan lebih ditingkatkan untuk pemberdayaan masyarakat desa dan pengembangan potensi ekonomi desa, hal ini untuk menghindari arus urbanisasi karena sampai saat ini persoalan fundamenanya dalah sangat terbatas bagi penduduk desa dalam mendapatkan peluang ataupun kesempatan dan lapangan kerja, disamping itu banyak perubahan fungsi lahan di desa yang membuat sebagian masyarakat desa yang masih berusia produktif hijrah dan memilih untuk mengadu nasib di kota dan bisa menimbulkan persoalan baru dalam perekonomian Nasional.

\section{Daftar Pustaka}

Badan Pusat Statistik. (2017). Badan Pusat Statistik (pp. 335-358). Badan Pusat Satistitik. https://doi.org/10.1055/s-2008-1040325

Bukhari, E. (2018). Kebijakan Dana Desa Dalam Usaha Pengentasan Kemiskinan Penduduk Pedesaan. Jurnal Administrasi Kantor Bina Insani, 6(2), 123-132. http://ejournalbinainsani.ac.id/index.php/JAKBl/article/view/1014/848

Buku Pintar Dana Desa. (2017). Buku Pintar Dana Desa. Buku Pintar Dana Desa, 113. https://www.kemenkeu.go.id/media/6749/buku-pintar-dana-desa.pdf

DPR. (2014). UU - Desa_no.6. 2014. http://www.dpr.go.id/dokjdih/document/uu/UU_2014_6.pdf Kemenkeu. (2017). Buku Saku Dana Desa. Kementerian Keuangan Republik Indonesia, 7. Nasution, A. (2016). Peranan Modal Sosial Dalam Pengurangan Kemiskinan Rumah Tangga Di Perdesaan Indonesia. Jurnal Ekonomi Dan Kebijakan Publik, 7(2), 171-183. 
Sudarlan. (2015). Pertumbuhan Ekonomi, Ketimpangan dan Kemiskinan di Indonesia. Eksis, 11(1), 3036-3213. http://karyailmiah.polnes.ac.id/images/Download-PDF/Dr. Sudarlan ST, MT/PertumbuhanKetimpangandanKemiskinan.pdf

Tambunan.TTH. (2012). Pembangunan Ekonomi dan Utang Luar Negeri (p. 221). Rajawali Press.

Wahyuddin, W., Ramly, A., Djalil, M. A., \& Indriani, M. (2019). Efektivitas Pemanfaatan Dana Desa dalam Mengentaskan Kemiskinan di Kec Kuala Kabupaten Nagan Raya. NUANSA: Jurnal Penelitian IImu Sosial Dan Keagamaan Islam, 16(2), 181. https://doi.org/10.19105/nuansa.v16i2.2410

Wicaksono, G., Puspita, Y., Bidhari, S. C., Kusumaningrum, N. D., \& Asmandani, V. (2019). Dan Pemberdayaan Masyarakat Desa Di Kabupaten. Jurnal Riset Dan Manajemen Dan Bisnis (JRMB) Fakultas Ekonomi UNIAT, 4(1), 9-20. 